\title{
Studies on the bioavailability of the provitamin A carotenoid, $\beta$-carotene, using human exfoliated colonic epithelial cells
}

\author{
T. Gireesh ${ }^{1}$, P. P. Nair ${ }^{2}$ and P. R. Sudhakaran ${ }^{1 *}$ \\ ${ }^{1}$ Department of Biochemistry, University of Kerala, Trivandrum, India 695581 \\ ${ }^{2}$ Department of International Health, Johns Hopkins University, Baltimore, USA
}

(Received 4 April 2003 - Revised 27 February 2004 - Accepted 3 March 2004)

\begin{abstract}
The possibility of using exfoliated colonic epithelial cells for assessing the bioavailability of $\beta$-carotene was examined. Analysis of exfoliated colonic epithelial cells showed the presence of $\beta$-carotene and vitamin A. The $\beta$-carotene content was significantly lower in cells from stool samples of subjects on a $\beta$-carotene-poor diet than those receiving a single dose of a $\beta$-carotene supplement. Colonic epithelial cells isolated from stool samples collected daily during a wash-out period while the subjects were on a $\beta$-carotene-poor diet showed a steady decrease in $\beta$-carotene content, reaching the lowest value on day 7. Kinetic analysis showed that a single dose of a $\beta$-carotene supplement in the form of spirulina (Spirulina platensis) or agathi (Sesbania grandiflora) after the wash-out period caused an increase in the $\beta$-carotene content after a lag period of $5-7 \mathrm{~d}$, but the vitamin A levels during these periods were not significantly affected. Analysis of plasma $\beta$-carotene concentration also showed similar changes, which correlated with those of exfoliated colonic cells. A relationship between the $\beta$-carotene content of the diet and that of the colonic epithelial cells suggests that analysis of the $\beta$-carotene content in exfoliated human colonic epithelial cells is a useful non-invasive method to assess the bioavailability of provitamin A $\beta$-carotene.
\end{abstract}

Bioavailability: Vitamin A: $\beta$-Carotene: Colonic epithelial cells

The role of vitamin A in eyesight, reproduction, gene expression, cell differentiation, and development has been well established. Dietary carotenoids are an important source of vitamin A for normal metabolic and physiological functions (Frank, 1996). Vitamin A deficiency has been recognized as a common public heath problem in many parts of the world and it is a serious problem in many developing countries (Ye et al. 2000). A number of factors may affect the bioavailability of provitamin A carotenoids, such as their conversion to vitamin A, rate of absorption, transport, chemical nature, and the fat content of the diet. Bioconversion of plant carotenoids to vitamin A varies inversely with vitamin A status; improvements in the vitamin A status after dietary intervention are influenced by total body stores of vitamin A, not by serum retinol level (Ribaya-Mercado et al. 2000). The type of food matrix in which carotenoids are located is a major factor. The bioavailability of $\beta$-carotene from vegetables in particular has been reported to be low ( $14 \%$ from mixed vegetables) compared with that of purified $\beta$-carotene added to a simple matrix (e.g. salad dressing), whereas for lutein the difference was much less (relative bioavailability $67 \%$ from mixed vegetables; Van het Hof et al. 2000). Vitamin A status is assessed at different levels. However, routine measurement of plasma vitamin A may not be a good indicator of status, as vitamin A concentration in the plasma is often 'buffered'; the best indicator is the liver concentration of vitamin A. The sensitivity and specificity of tools for assessment of vitamin A status in the suboptimal and/or marginal range seem to be inadequate (Van den Berg, 1996). Invasive sampling of blood and liver biopsies are not feasible in field investigations and there are no noninvasive methods to assess the provitamin $\mathrm{A}$-vitamin $\mathrm{A}$ status in a target population.

Apart from non-descript heterogeneous waste materials, human stools also contain viable exfoliated colonic epithelial cells (Albaugh et al. 1992). Recent advances in the biology of the gut have made it possible to obtain pure exfoliated viable cells from human stools for metabolic studies (Nair et al. 1996). In the present study, exfoliated colonic epithelial cells isolated from subjects taking diets either rich or poor in provitamin A carotenoids were used to assess $\beta$-carotene distribution and its bioavailability. The results suggest the potential value of this non-invasive technique to evaluate the bioavailability of provitamin A.

\section{Experimental methods}

Pre-formulated medium for transportation of stool and isolation of colonic epithelial cells was supplied by M/s Noninvasive Technologies, Columbia, MD, USA. Spirulina (Spirulina platensis; Multinol, Parry Nutraceuticals Ltd, Chennai, India) pellets and authenticated standards of $\beta$-carotene (Sigma Chemical Co., St. Louis, USA) and retinol (Hoffmann-La Roche, Basle, Switzerland) were used. 
High-purity HPLC grade solvents (Merck, Mumbai, India) were used.

\section{Separation of colonic epithelial cells}

Exfoliated colonic epithelial cells were isolated by a modified procedure of Albaugh et al. (1992). Approximately $500 \mathrm{mg}$ stool was put into a container with transport medium (SCSR-T; Non-invasive Technologies, Columbia, USA) using a spatula attached to the stopper and kept at $4^{\circ} \mathrm{C}$. On arrival, the stool samples were thoroughly mixed using a vortex mixer for approximately $15 \mathrm{~s}$. The suspension was then filtered through a $40 \mu \mathrm{m}$ filter into $50 \mathrm{ml}$ stoppered polypropylene tubes and additional transport medium was added to make up the volume to $25 \mathrm{ml}$. The cushion (SCSR-T, $10 \mathrm{ml}$ ) was underlaid beneath the suspension and the tubes centrifuged at $200 \mathrm{~g}$ for $10 \mathrm{~min}$. The contents separated into layers: a supernatant fraction, a lower pellet and an interphase between them. Accumulated cells at the interphase and those present in the bottom layer were removed carefully using a sterile pipette. The supernatant fraction up to the interphase was discarded. The recovered cells were washed thoroughly with PBS and collected by centrifugation at high speed $(1000 \mathrm{~g})$. The viability of the cells was determined by Trypan Blue exclusion and the protein content was estimated using the method of Lowry et al. (1951). About $60-70 \%$ of the cells were viable, as evidenced by exclusion of Trypan Blue. The yield of the cells was in the range $1.0 \times 10^{6}$ to $1.5 \times 10^{6}$ cells/g stool sample and the analysis of multiple samples showed $<10 \%$ variation within the samples. During the isolation steps, accumulation of viable colonic epithelial cells was observed in the interphase fraction and cushion-pellet fraction. The majority of viable cells were obtained from the interphase.

\section{Extraction of $\beta$-carotene from colonic epithelial cells and HPLC analysis}

Known quantities of isolated colonic epithelial cells were stored in amber-coloured screw-capped vials at $-20^{\circ} \mathrm{C}$ until they were extracted with solvents (storage was for less than 4 weeks). Cell pellets were subjected to sonication at $27^{\circ} \mathrm{C}$ for $10 \mathrm{~min}$ and then saponified using $\mathrm{KOH}$ $(100 \mathrm{~g} / \mathrm{l} \mathrm{methanol})$ for $3 \mathrm{~h}$ at room temperature. The saponified samples were extracted three times with hexane and the pooled extracts were concentrated, washed with absolute ethanol and water. The recovered hexane layer was evaporated under $\mathrm{N}_{2}$ gas, redissolved in ethanol (undiluted) and analysed by HPLC. In order to protect the samples from oxidative damage, all operations were carried out under subdued light and $\mathrm{N}_{2}$ atmosphere.

HPLC analysis was done using a SPD 10A Shimadzu liquid chromatograph (Shimadzu Corporation, Kyoto, Japan) operating at room temperature. A Whatman Partisil-5 ODS 3 column was used (Whatman, Whatman Plc, Kent, UK). Freshly prepared degassed mobile phase (acetonitrile-chloroform-isopropanol-water (780:160:35:25, by vol.)) was used. The flow rate was adjusted to $2 \cdot 0 \mathrm{ml} / \mathrm{min}$. $\beta$-Carotene was measured at $450 \mathrm{~nm}$ and retinol at $325 \mathrm{~nm}$. Authenticated samples of $\beta$-carotene, lutein and retinol and other carotenoids were used to identify the respective retention time and peak area measurements were used for calculation. The carotenoids extracted from cells from $500 \mathrm{mg}$ stool sample were sufficient for eight to ten replicate analyses; the detection limit at high resolution setting was $10 \mathrm{ng}$ (in injected sample). Each sample was analysed in duplicate.

\section{Extraction and analysis of supplements}

Carotenoids were extracted from spirulina and agathi (Sesbania grandiflora) and analysed by HPLC as described by Gireesh et al. (2001). The results are given in Table 1.

\section{Subjects}

Subjects were selected based on their ability to comply with different dietary regimens, after informed consent had been obtained. Volunteers from the laboratory provided stool samples for isolation of colonic epithelial cells. A daily diet diary was maintained and average intakes of energy, $\beta$-carotene, fat and protein were calculated (Gopalan et al. 1995).

The study design is shown in the flow chart in Fig. 1. Nine subjects aged 21-24 years were recruited for the study and divided into three groups of three each. All the subjects ate a carotenoid-poor diet for 3 weeks (preparatory phase). At the end of the third week subjects in groups 2 and 3 took a carotenoid-containing diet and those in group 1 continued on the carotenoid-poor diet for $7 \mathrm{~d}$. On day 7 stool samples were collected from all the subjects for isolation of exfoliated colonic epithelial cells for subsequent analysis of $\beta$-carotene. All the subjects then took a carotenoid-poor diet for another $7 \mathrm{~d}$ and stool samples were collected daily. At the end of the wash-out period, subjects in groups 2 and 3 took a bolus of $\beta$-carotene (group 2: supplement of cooked agathi, $1500 \mu \mathrm{g} \beta$-carotene; group 3, supplement of spirulina, $1800 \mu \mathrm{g} \beta$-carotene) followed by a $\beta$-carotene-poor diet for a further $7 \mathrm{~d}$. Subjects in group 1 continued to take the $\beta$-carotene-poor diet. Stool samples were collected daily and the colonic epithelial cells were isolated and subjected to HPLC analysis for $\beta$-carotene, lutein and retinol. Blood was also collected after the $\beta$-carotene supplementation

Table 1. Carotenoid composition of agathi (Sesbania grandiflora) and spirulina (Spirulina platensis) ( $\mu \mathrm{g} / \mathrm{g}$ wet wt of supplement)* (Mean values and standard deviations for analyses in triplicate)

\begin{tabular}{|c|c|c|c|c|}
\hline \multirow[b]{2}{*}{ Carotenoids } & \multicolumn{2}{|c|}{ Agathi $(\mu \mathrm{g} / \mathrm{g})$} & \multicolumn{2}{|c|}{ Spirulina $(\mu g / g)$} \\
\hline & Mean & SD & Mean & SD \\
\hline trans- $\beta$-Carotene & 184 & $5 \cdot 7$ & 457 & $8 \cdot 7$ \\
\hline$\alpha$-Carotene & 47 & $3 \cdot 2$ & 98 & $5 \cdot 0$ \\
\hline 9-cis- $\beta$-Carotene & 83 & $8 \cdot 1$ & 168 & 3.4 \\
\hline 13-cis- $\beta$-Carotene & 35 & $5 \cdot 0$ & 57 & $3 \cdot 0$ \\
\hline Lutein & - & - & 30 & 2.5 \\
\hline Zeaxanthin & 22 & 3.5 & 62 & $3 \cdot 8$ \\
\hline Cryptoxanthin & 80 & $7 \cdot 6$ & 26 & $5 \cdot 3$ \\
\hline Lycopene & 2 & 0.35 & - & - \\
\hline
\end{tabular}

* Carotenoids of spirulina and agathi, which were used as supplements, were extracted and analysed by HPLC. 


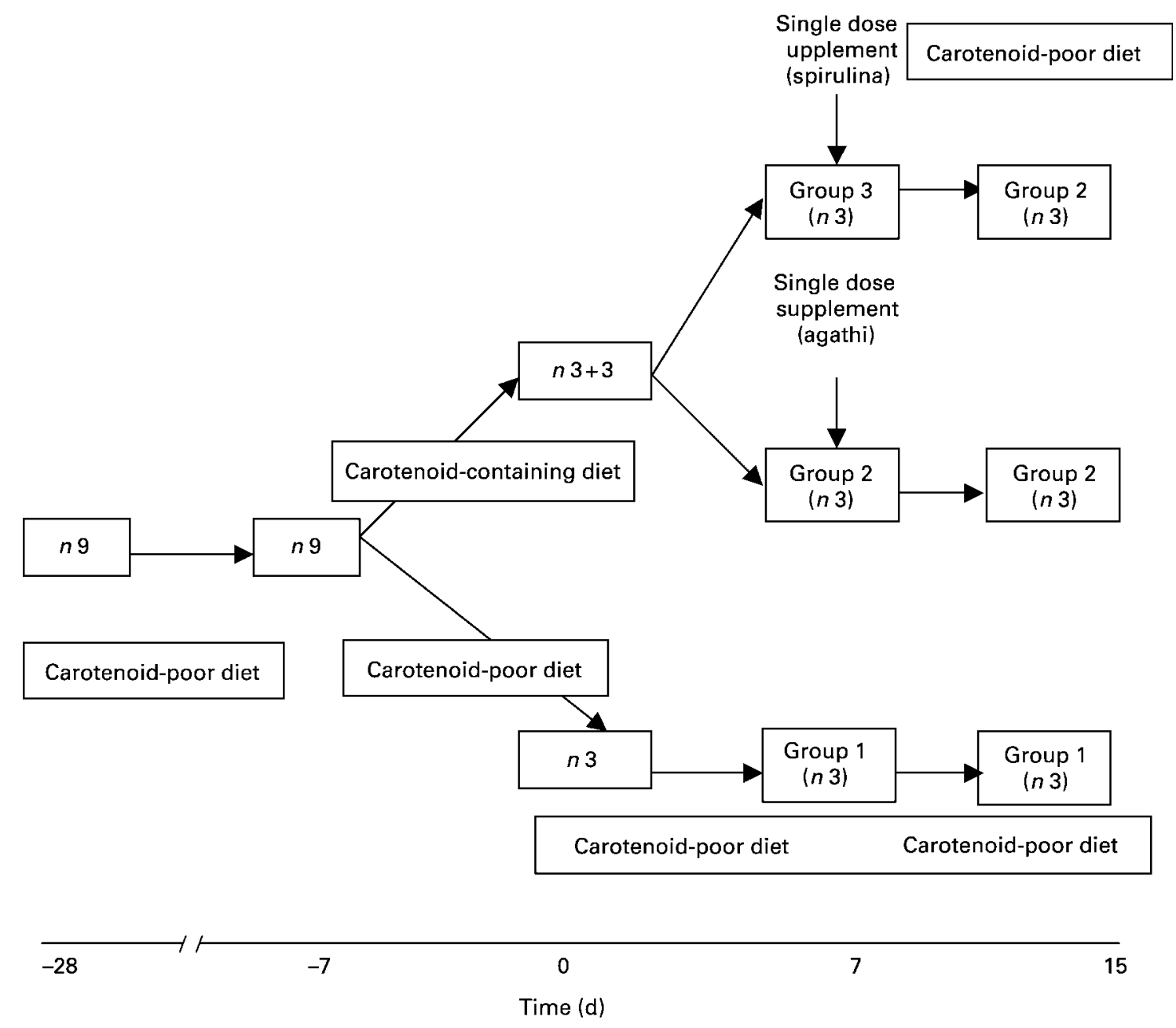

Fig. 1. Flow chart showing the design of the study.

from the subjects in group 3. Plasma was separated and subjected to $\beta$-carotene and retinol analysis. Statistical analysis was done using Student's $t$ test (Bennett \& Franklin, 1967).

\section{Results and discussion}

The colonic epithelial cells isolated from different stool samples were analysed for their $\beta$-carotene and vitamin A content and the results showed that $\beta$-carotene and retinol were present in both interphase and pellet fraction of the cells. However, the cells in the interphase fraction contained significantly greater amounts of $\beta$-carotene than the pellet (range $0.0207-0.0500 \mu \mathrm{g} / \mathrm{mg}$ protein). In order to examine whether the levels of $\beta$-carotene in the diet had any effect on the level of $\beta$-carotene in these cells, subjects ( $n$ 9) who had been in the preparatory phase for 3 weeks were divided into three groups of three each (day 7 on flow chart, Fig. 1). Subjects in group 1 took a carotenoid-poor diet and those in group 2 and 3 took carotenoidcontaining diet for $7 \mathrm{~d}$. The average nutrient intake and energy in the diets were determined. The total amount of protein ingested by each subject was $59-62 \mathrm{~g} / \mathrm{d}$ and that of fat was $41-46 \mathrm{~g} / \mathrm{d}$. The cells were collected from stool samples of these subjects after $7 \mathrm{~d}$ (day 0 in the flow chart, Fig. 1); the $\beta$-carotene and vitamin A levels were determined and the results are shown in Table 2 . The $\beta$-carotene content was significantly lower in cells from stool samples of subjects on a $\beta$-carotene-poor diet than from those receiving the single $\beta$-carotene supplement. This was analysed further by collecting stool samples daily after a wash-out period, when all these subjects were placed on a $\beta$-carotene-poor diet. The results are given in Fig. 2 . There was a steady decrease in the $\beta$-carotene content and this was lowest on day 7. On day 7 the subjects had a spirulina + agathi-supplemented diet and the stool samples were then collected daily for analysis of $\beta$-carotene and vitamin $\mathrm{A}$ in exfoliated cells. The kinetics of accumulation of $\beta$-carotene are shown in Fig. 2. The $\beta$-carotene level in the exfoliated cells of carotenoidsupplemented subjects increased progressively and attained a maximum value on day 6 (day 13 in the flow chart, Fig. 1) and declined thereafter. However, there was no significant difference in the retinol content in the cells from subjects of different groups, nor was there any change in the intake of $\beta$-carotene during the period of the study. The retinol content was $20-85 \mathrm{ng} / \mathrm{mg}$ cell protein.

In order to examine whether there was any correlation between the plasma level of carotenoids and that of exfoliated colonic cells, blood was collected on different days from the subjects after the ingestion of a single dose of 
Table 2. Change in $\beta$-carotene and retinol content in exfoliated colonic epithelial cells with change in the $\beta$-carotene content of the diets* (Mean values with their standard errors for three subjects per group with analyses in duplicate)

$\beta$-Carotene and retinol content ( $\mathrm{ng} / \mathrm{mg}$ cell protein) in colonic epithelial cells

\begin{tabular}{|c|c|c|c|c|c|c|c|c|c|c|c|c|c|}
\hline \multirow[b]{4}{*}{ Group } & \multirow[b]{4}{*}{ Type of diet } & \multirow{2}{*}{\multicolumn{4}{|c|}{ Average nutrient intake (per d) }} & \multirow{2}{*}{\multicolumn{4}{|c|}{$\beta$-Carotene }} & \multirow{2}{*}{\multicolumn{4}{|c|}{ Retinol }} \\
\hline & & & & & & & & & & & & & \\
\hline & & \multirow{2}{*}{$\begin{array}{l}\text { Protein } \\
\text { (g) }\end{array}$} & \multirow{2}{*}{$\begin{array}{l}\text { Fat } \\
(\mathrm{g})\end{array}$} & \multirow{2}{*}{$\begin{array}{l}\text { Energy } \\
\text { (kJ) }\end{array}$} & \multirow{2}{*}{$\begin{array}{l}\beta \text {-carotene } \\
(\mu \mathrm{g})\end{array}$} & \multicolumn{2}{|c|}{ Interphase } & \multicolumn{2}{|c|}{ Pellet } & \multicolumn{2}{|c|}{ Interphase } & \multicolumn{2}{|c|}{ Pellet } \\
\hline & & & & & & Mean & $\overline{S E}$ & Mean & $\overline{S E}$ & Mean & $\overline{\mathrm{SE}}$ & Mean & $\overline{\mathrm{SE}}$ \\
\hline 1 & $\beta$-Carotene poor & $59 \cdot 2$ & $42 \cdot 4$ & 9016 & 95 & $14 \cdot 3$ & $2 \cdot 1$ & $9 \cdot 3$ & $2 \cdot 0$ & 63.0 & $4 \cdot 3$ & $23 \cdot 0$ & $2 \cdot 0$ \\
\hline 2 & $\beta$-Carotene rich & $60 \cdot 8$ & $45 \cdot 7$ & 11730 & 1500 & $38 \cdot 1$ & 4.5 & $30 \cdot 0$ & 4.9 & $75 \cdot 0$ & 2.4 & $34 \cdot 0$ & 3.0 \\
\hline 3 & $\beta$-Carotene rich & $62 \cdot 0$ & $40 \cdot 6$ & 10894 & 1800 & $50 \cdot 6$ & $5 \cdot 6$ & $43 \cdot 0$ & $4 \cdot 3$ & 80.0 & $3 \cdot 3$ & $42 \cdot 5$ & $2 \cdot 7$ \\
\hline
\end{tabular}

* Subjects in groups 2 and 3 received a carotenoid-containing diet and those in group 2 received a carotenoid-poor diet for $7 \mathrm{~d}$ after a preparatory phase of 3 weeks as indicated in Fig. 1. The daily intakes of protein, fat and $\beta$-carotene were calculated from the diet diary. Exfoliated colonic epithelial cells were isolated from the subjects after $7 \mathrm{~d}$ (day 0 in the flow chart, Fig. 1) and the distribution of $\beta$-carotene and retinol in different fractions of the cells were analysed using HPLC.

$\beta$-carotene-rich spirulina supplements and the plasma level of $\beta$-carotene and retinol were analysed; the results are shown in Table 3. $\beta$-Carotene content increased steadily from a basal level (day 0 on flow chart, Fig. 1) of 3.7$4.7 \mathrm{mg} / \mathrm{l}$ on day 6 and then declined to basal level on day 10 , while there was no significant change in the retinol level in the plasma during this period. These results suggest that the exfoliated colonic cells may be loaded with $\beta$-carotene provided by the blood and not by any direct transfer from carotenoid supplements.

Lutein is another carotenoid present in spirulina (about $37 \%$ of total carotenoids; Table 1). Analysis of carotenoids of colonic epithelial cells showed that cells from subjects who took spirulina-containing supplement contained a significant amount of lutein, and the level of lutein increased from 0.0100 to $0.0470 \mu \mathrm{g} / \mathrm{mg}$ cell protein during the $6 \mathrm{~d}$ after supplementation; the pattern of change was similar to the changes in the level of $\beta$-carotene. The increase in the lutein content of colonic epithelial cells seemed to serve as an internal marker, suggesting that the changes in $\beta$-carotene content in colonic epithelial cell were due to an increase in its bioavailability.

Analysis of carotenoids from the exfoliated colonic epithelial cells indicates that there is a significant relationship between the intake of dietary carotenoids and $\beta$-carotene content of colonic epithelial cells. This is based on the following observations. (1) $\beta$-Carotene and vitamin A contents in exfoliated colonic epithelial cells from subjects who were taking diets poor in provitamin A carotenoids were very low. (2) Intake of a $\beta$-carotene supplement resulted in an increase in the $\beta$-carotene content in exfoliated colonic epithelial cells. An increase in the content of lutein, which served as an internal marker from spirulina, suggested that the $\beta$-carotene is also of dietary origin and suggested an increase in its bioavailability. A correlation between changes in $\beta$-carotene content in plasma and that in exfoliated colonic epithelial cells suggests that these cells are loaded with the $\beta$-carotene

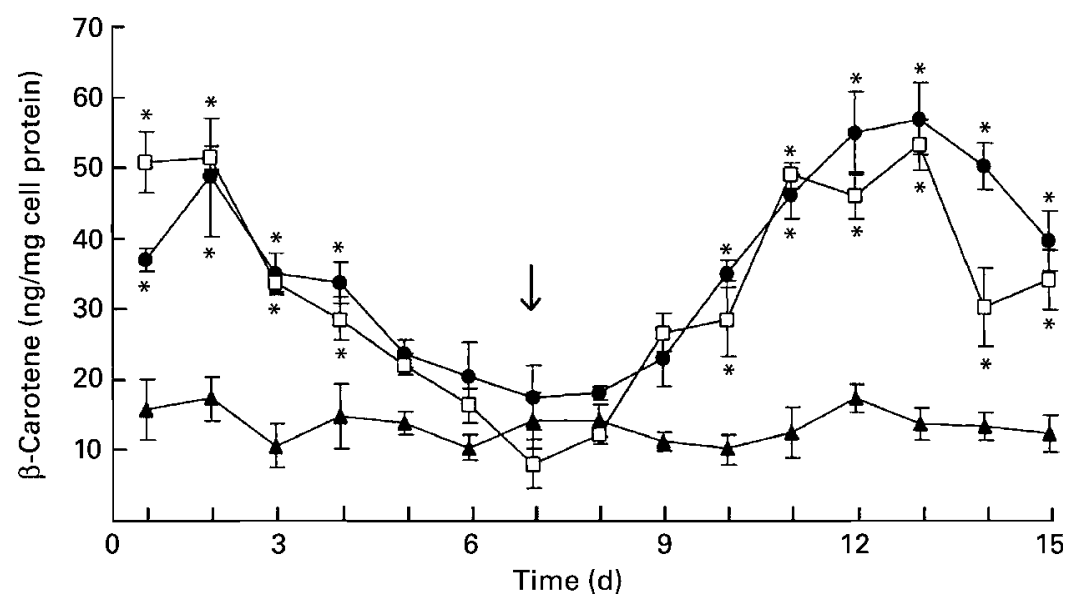

Fig. 2. Kinetics of the distribution of $\beta$-carotene in exfoliated human colonic epithelial cells. Subjects were divided into three groups (three per group) and those in groups 2 and 3 received a $\beta$-carotene-containing diet, while those in group 1 received a $\beta$-carotene-poor diet, as described on p. 242 (day 0). Subjects in all the groups then had a $\beta$-carotene-poor diet for $7 \mathrm{~d}$. At the end of the wash-out period subjects in group 2 ( $)$ took a bolus of cooked agathi (Sesbania grandiflora; $1500 \mu \mathrm{g} \beta$-carotene) and those in group 3 ( $\square$ ) took a bolus of spirulina (Spirulina platensis; 1800; $\mu \mathrm{g} \beta$-carotene). Those in group $1(\boldsymbol{\Lambda})$ served as control, with no supplements. After supplementation ( $\downarrow$ ), subjects in groups 2 and 3 took a $\beta$-carotene-poor diet for another $7 \mathrm{~d}$. Stool samples were collected daily from all subjects and cells were isolated and subjected to analysis. Values are means with their standard errors $(n 3)$. Mean values were significantly different from those of group 1 at the same time point: * $P<0.05$. 
Table 3. Kinetics of plasma uptake of $\beta$-carotene and retinol†

(Mean values with their standard errors for three subjects per group with analyses in duplicate)

\begin{tabular}{|c|c|c|c|c|c|c|c|c|c|c|c|c|}
\hline \multirow[b]{3}{*}{ Components (mg/l) } & \multicolumn{12}{|c|}{ Time after ingestion $\ddagger$} \\
\hline & \multicolumn{2}{|c|}{1} & \multicolumn{2}{|c|}{ II } & \multicolumn{2}{|c|}{ III } & \multicolumn{2}{|c|}{ IV } & \multicolumn{2}{|c|}{ V } & \multicolumn{2}{|c|}{ VI } \\
\hline & Mean & SE & Mean & SE & Mean & SE & Mean & SE & Mean & SE & Mean & SE \\
\hline$\beta$-Carotene & $3 \cdot 67$ & 0.25 & $3 \cdot 76$ & 0.28 & 3.88 & 0.25 & $4 \cdot 34$ & 0.27 & $4 \cdot 66^{\star}$ & 0.24 & 3.70 & 0.28 \\
\hline Retinol & $2 \cdot 80$ & 0.13 & 2.44 & 0.20 & 2.94 & 0.14 & 2.73 & 0.04 & 2.48 & 0.19 & $2 \cdot 80$ & 0.15 \\
\hline
\end{tabular}

Mean value was significantly different from that at time I: ${ }^{*} P<0.05$.

†Blood was collected at regular intervals from subjects in group 3 who received a single dose of Spirulina platensis as described in the legend to Fig. 1. Plasma was separated and $\beta$-carotene and retinol were analysed.

¥Time after ingestion I, II, III, IV, V and VI correspond to days 7, 9, 10, 11, 13 and 15 in Fig. 2 respectively.

provided from the blood. Variability in the viability and corresponding $\beta$-carotene content in the different fractions of the cells under different dietary regimens is a reflection of their origin and age in the gut: the most senescent population is present in the lighter fraction, which appeared in the interphase fraction. Our present results confirm an earlier report (Nair et al. 1996), wherein various sub-populations of colonic epithelial cells have been identified. Analysis of the $\beta$-carotene content in the colonic epithelial cells from subjects who took a $\beta$-carotene supplement after the wash-out period, when a $\beta$-carotene-poor diet was taken, revealed that a lag period of $5-7 \mathrm{~d}$ was required for the changes in carotenoid content in the exfoliated colonic epithelial cells. It coincides with the reported turnover rate of the epithelium and its migration from proliferatory zone to luminal surface (Lepkin, 1973). Withdrawal of $\beta$-carotene from the diet caused a decrease in the $\beta$-carotene content in the cell and reached a minimum value on day 7 after the withdrawal of $\beta$-carotene. However, retinol content in the cells remained almost at the same level during this period. When the $\beta$-carotene-poor diet was taken by the subjects for up to 2 weeks, the level of $\beta$-carotene in these cells remained as low as $0.0100-0.0173 \mu \mathrm{g} /$ $\mathrm{mg}$ cell protein, while the retinol level was 0.0700$0.0976 \mu \mathrm{g} / \mathrm{mg}$ cell protein, which was similar to that of subjects receiving the $\beta$-carotene supplement. The amount of vitamin A that is metabolically derived from specific carotene-containing foods is unknown (Edwards et al. 2001).

The present study indicates that micronutrient analysis, particularly $\beta$-carotene in the colonic epithelial cell, is a useful non-invasive method to assess the bioavailability of pro-vitamin A carotenoids and the efficacy of intervention studies involving dietary supplementation. It requires further validation using a large number of samples, particularly children at different stages of growth.

\section{Acknowledgements}

This work was funded by International Atomic Energy Agency Vienna, Austria (contract no. 11529/RO). The authors are also thankful to Dr V. Iyengar of the International Atomic Energy Agency, Vienna, Austria, for his keen interest in the project.

\section{References}

Albaugh GP, Iyengar V, Lohani A, Malayeri M, Bala S \& Nair PP (1992) Isolation of exfoliated colonic epithelial cells, a novel, non-invasive approach to the study of cellular markers. Int $J$ Cancer 52, 347-350.

Bennett CA \& Franklin NL (1967) Mathematical machinery. In Statistical Analysis in Chemistry and the Chemical Industry, pp. 677-684. New York: John Wiley \& Sons, Inc.

Edwards AJ, You CS, Swanson JE \& Parker RS (2001) A novel extrinsic reference method for assessing the vitamin A value of plant foods. Am J Clin Nutr 74, 348-355.

Frank HA (1996) Structural determinations and spectroscopic studies of carotenoids reveal the factors important in controlling their function in biological systems. Eur J Clin Nutr 50, S13-S16.

Gireesh T, Jayadeep A, Rajasekharan KN, Menon VP, Vairamany M, Tang G, Nair PP \& Sudhakaran PR (2001) Production of deuterated $\beta$-carotene by metabolic labeling of Spirulina platensis. Biotechnol Lett 23, 447-449.

Gopalan C, Ramasasthri BV \& Balasubramanyan SC (1995) Nutritive Value of Indian Foods, pp. 43-97. Hyderabad: National Institute of Nutrition, Indian Council of Medical Research.

Lepkin M (1973) Proliferation and differentiation of gastrointestinal cells. Phys Rev 53, 891-915.

Lowry OH, Rosebrough NJ, Farr AL \& Randall RJ (1951) Protein measurement with the Folin-phenol reagent. J Biol Chem 193, $265-275$.

Nair PP, Lohani A, Norkus EP, Feagins H \& Bhagavan HN (1996) Uptake and distribution of carotenoids, retinol and tocopherols in human colonic epithelial cells in vivo. Cancer Epidemiol Biomarker Prev 5, 913-916.

Ribaya-Mercado JD, Solon FS, Solon MA, Cabel-Barza MA, Perfecto CS, Tang G, Solon JA, Fjeld CR \& Russel RM (2000) Bioconversion of plant carotenoids to vitamin A in Filipino school-aged children varies inversely with vitamin A status. Am J Clin Nutr 72, 455-465.

Van den Berg H (1996) Vitamin A intake and status. Eur J Clin Nutr 50, S7-S12.

Van het Hof K, West CE, Weststrate JA \& Hautvast JGAJ (2000) Dietary factors that affect the bioavailability of caroteniods. J Nutr 130, 503-506.

Ye X, Al-Babili S, Kloti A, Zhang J, Lucca P, Beyer P \& Potrykus I (2000) Engineering the provitamin A ( $\beta$-carotene) biosynthetic pathway into (carotenoid-free) rice endosperm. Science 287, 303-305. 